\title{
Experimental Study of the Aphanizomenon ovalisporum Response to Nitrogen Fertilization in the Sub-Tropical Eu-Meso-Trophic Lake Kinneret (Israel)
}

\author{
Moshe Gophen \\ Migal Scientific Research Institute, Kiryat Shmone, Israel \\ Email: Gophen@Migal.org.il \\ Received 28 April 2015; accepted 31 May 2015; published 3 June 2015 \\ Copyright (C) 2015 by author and Scientific Research Publishing Inc. \\ This work is licensed under the Creative Commons Attribution International License (CC BY). \\ http://creativecommons.org/licenses/by/4.0/

(c) (i) Open Access

\begin{abstract}
First record of a bloom of filamentous-heterocystous nitrogen fixer cyanobacterium, Aphanizomenon ovalisporum, was documented in the summer of 1994 in Lake Kinneret (Israel). Awareness of such a bloom outbreak was predicted earlier based on documentation of Nitrogen deficiency and Phosphorus Sufficiency developed conditions. The concept of Nitrogen fertilization aimed at suppression of Nitrogen fixers Cyanobacteria was worldwide discussed and successfully implemented, but mostly in temperate oligotrophic lake ecosystems. This paper presents an experimental testing of this concept by additional Nitrogen. The results of the present study did not verify this hypothesis probably related to the ecological differences between Kinneret and the temperate ecosystems and using only one factor (Nitrogen) to test it.
\end{abstract}

Keywords

Aphanizomenon, N-Fertilization, Limnological Conditions

\section{Introduction}

The $\mathrm{N}_{2}$ fixing cyanobacterium, the filamentous-heterocystous Aphanizomenon ovalisporum (Forti), was recorded for the first time in Lake Kinneret in August 1994 forming a heavy bloom from September through October. Low densities of $A$. ovalisporum were also observed from the summer of 1995 and onwards in the newly created shallow Lake Agmon in the Kinneret drainage basin (Hula Valley). Lake Agmon was constructed during the second half of 1994 and filled with Jordan River water first time in late summer. Several factors were suggested 
as stimulators of the Aphanizomenon bloom in Lake Kinneret: high temperatures, low wind velocity regime affected low turbulence, increase of bio-available Phosphorus inputs and internal fluxes. Nevertheless, Nitrogen deficiency combined simultaneously with Phosphorus sufficiency was not distinctly considered by the relevant authorities. Awareness considerations of potential outbreak of Nitrogen fixing cyanobacteria in Lake Kinneret started much earlier, during 1987. Analysis of long-term changes of N \& P regimes in Lake Kinneret that was focused on the reduction of Nitrogen and a slight increase of Phosphorus availabilities resulted in a decline of N/P ratio was the major concern [1] [2]. Significant enhancement of the study of $\mathrm{N}_{2}$-fixer cyanophytes invasion to Lake Kinneret was stimulated by the Key-stone paper in [2]. Nevertheless, seven years before the Aphanizomenon burst in August 1994, the author was trying intensively to enhance awareness to the risk of $\mathrm{N}_{2}$-fixing Cyanobacterium in Lake Kinneret. It was done through International and Local national Papers, lectures, workshops and others. This direction was rejected by water authorities. Nevertheless, investigations were focused on two major scopes: 1) To identify the potential ecological background for the Aphanizomenon bloom outburst in Lake Kinneret; and 2) To indicate potential measure, possibly through anthropogenic intervention, for the reduction of this cyanophyte bloom. Due to seasonal and temporal fluctuations of the Cyanobacteria together with regard to the safety of water quality, the $2^{\text {nd }}$ scope received higher priority due to its critical trait of ensuring drinking water supply from the lake. A comprehensive study of the importance priorities of ecological factors which enhance the development of $\mathrm{N}$ fixing Cyanobacteria was documented recently [3]. They concluded that the best explanation of variations among lakes in the rate of Cyanobacteria enhancement is due to nutrient (P, $\mathrm{N}$ ) concentrations and temperature is of secondary importance. The conceptual merit of studies presented in [2]-[5], and others, is the following: because low N/P mass ratio is the dominant factor affecting proliferation of Cyanobacteria the backward direction might be logically efficient: $\mathrm{P}$ removal, $\mathrm{N}$ fertilizing, or both as a tool for Cyanobacteria suppression. The first record of Aphanizomenon outbreak during the summer of 1994 which followed long term decline of N/P mass ratio was therefore an obvious subject for $\mathrm{N}$ fertilizing research and the results are presented in this paper.

\section{Material and Methods}

The study was carried out in 4 pairs of outdoor $5 \mathrm{~m}^{3}$ tanks directly installed to the lake water through a plastic pipe ended by an intake located in the shallows $30 \mathrm{~cm}$ above bottom and $35 \mathrm{~m}$ apart from the shoreline. In order to produce effect of turbulence the tanks were continuously gently aerated 24 hours a day by an airlift apparatus connected to compressor which pressed air through pipes with an open end close to the tank bottom. The tanks were filled with Lake shallow water containing heavy bloom of Aphanizomenon and one of each pair was fertilized by addition of $1.5 \mathrm{Kg}$ of $\mathrm{NH}_{4} \mathrm{Cl}$. The trial continued 20 days. The biomass of the cyanophytes was approximated to comprise $>70 \%$ of the phytoplankton in the water. There was no water exchange and samples were collected every 4 days by 1L sampler. Sampling procedure was as follow: Three 1L separated samples were mixed and the mixed samples were sub-sampled for chemistry, chlorophyll and filament counts. Filament counts were not done in days 16 and 20 due to technical difficulties. Chemical analysis included: Total and Dissolved Kijeldhal, Total Inorganic Nitrogen ( $\mathrm{NO}_{3}$, and Ammonia, Nitrite was neglected), Particulate Nitrogen, Particulate Phosphorus, Total Algal DW (accounted to total particulate Matter considered as algal matter). The methods for chemical and chlorophyll analysis are given in [6]. The chemical analysis was carried out in duplicates and results were averaged. Filament counts were done on $5 \mathrm{ml}$ subsamples preserved by Lugol and left for 24 hours for complete sedimentation in counting chambers and counting randomized chosen 10 field views in Zeise M20 inverted microscope. The first sampling was done before the addition of $\mathrm{NH}_{4} \mathrm{Cl}$. All daily and duplicated tank results were averaged for one daily mean.

\section{Results}

Data given in Figure 1 represent the daily changes of the following parameters: TIN, Dissolved Kijeldhal, Total Kijeldhal, mass ratio between particulate Nitrogen and particulate Phosphorus (PN/PP), Nitrogen content per Algal matter (dw), Chlorophyll content, as averaged for the two replicated tanks with and without Nitrogen addition. It is prominent that with the addition of Nitrogen the values of TIN, PN/PP, Total Kijeldhal, and Chlorophyll content, where higher in tanks with additional $\mathrm{N}$ than in those without it. The values of Dissolved Kijeldhal in the tanks without additional nitrogen were lower only during the last two days of the trial. The higher filament densities throughout the entire experimental period are evidently shown In Figure 1. The close level values 
of Nitrogen content in the filaments (N/algal dw matter) in tanks with and without additional $\mathrm{N}$ is probably an indication for stable $\mathrm{N}$ content but dissimilarity was documented between values of filament densities. Consequently changes of chlorophyll content might be related to filament densities changes. The results of ANOVA test $(\mathrm{p}<0.05)$ presented in Figure 1 (right panel) indicates the higher filament densities observed in tanks with additional Nitrogen. The total averaged values measured every 4 days during 20 days in the tanks with and without additional Nitrogen are given in Table 1.

All averaged values were tested by Paired t-test and p values are given in Table 2.

Results in Table 2 indicate higher chlorophyll content, higher TIN concentration, and higher Total Kijeldhal concentration in tanks with additional Nitrogen. Whereas other parameters were not statistically different between Tanks with and without additional Nitrogen.
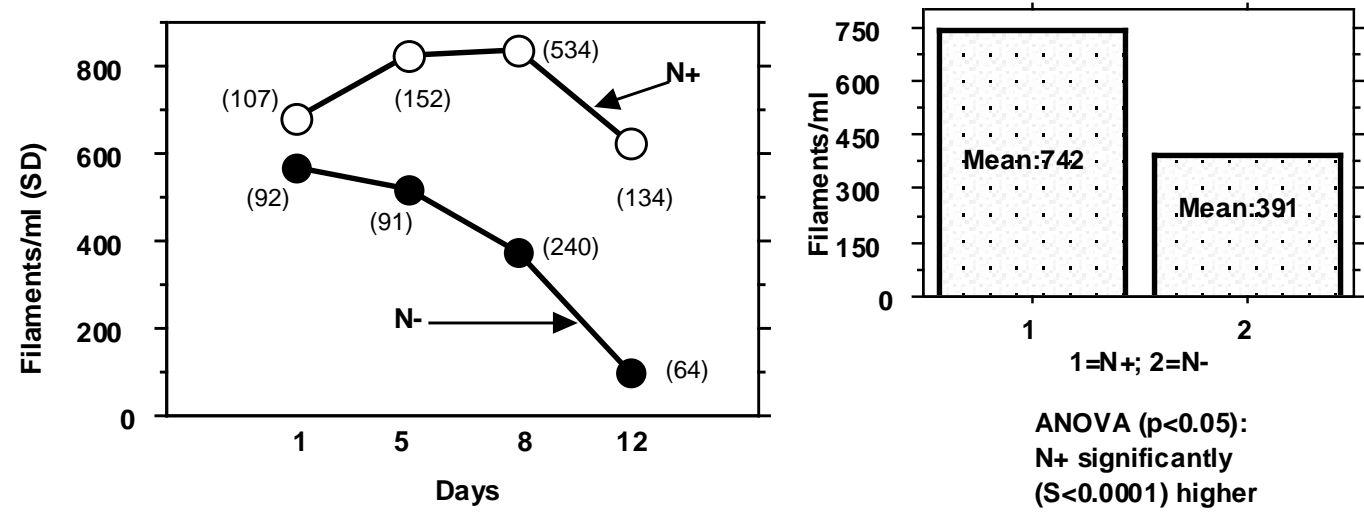

Figure 1. Left Panel: Filament densities (No./ml): all counts were averaged (SD in brackets); Right panel: Comparative ANOVA $(\mathrm{p}<0.05)$ test Between with $\left(\mathrm{N}^{+}\right)$and without $\left(\mathrm{N}^{-}\right)$Additional Nitrogen.

Table 1. Total averages for two duplicates of chemical and biological parameters collected every 4 days during 20 days for tanks with and without Nitrogen addition.

\begin{tabular}{ccc|}
\hline Parameter & Without additional $\mathrm{N}$ & With additional $\mathrm{N}$ \\
\hline Chlorophyll $\left(\mathrm{mg} / \mathrm{m}^{3}\right)$ & 8.4 & 11.4 \\
TIN $(\mathrm{ppm})$ & 0.088 & 0.181 \\
Total Kijeldhal $(\mathrm{ppm})$ & 0.37 & 0.44 \\
N/Algal dw $\left(\mathrm{mg} / \mathrm{m}^{3}\right)$ & 0.067 & 0.074 \\
PN/PP mass ratio & 14.6 & 19.3 \\
Dossolved Kijeldhal $(\mathrm{ppm})$ & 0.30 & 0.33 \\
\hline
\end{tabular}

Table 2. p-values (greater or smaller than 0.05 ) of Paired (With and without additional Nitrogen) t-test of total averages (6 daily samples and two treatment replicates): $\mathrm{S}=$ Significant statistical difference; NS = No significant statistical difference.

\begin{tabular}{cc} 
Parameter & p-value \\
\hline Chlorophyll $\left(\mathrm{mg} / \mathrm{m}^{3}\right)$ & $0.0079 \mathrm{~S}$ \\
TIN $(\mathrm{ppm})$ & $0.0050 \mathrm{~S}$ \\
Total Kijeldhal $(\mathrm{ppm})$ & $0.0049 \mathrm{~S}$ \\
N/Algal dw $\left(\mathrm{mg} / \mathrm{m}^{3}\right)$ & $0.4423 \mathrm{NS}$ \\
PN/PP mass ratio & $0.3693 \mathrm{NS}$ \\
Dossolved Kijeldhal (ppm) & $0.0738 \mathrm{NS}$ \\
\hline
\end{tabular}




\section{Discussion}

The relation between Cyanobacteria and nutrients (N, P) composition was widely investigated and documented. Due to the toxicity of these algae the reverse potential opportunities was also intensively investigated. $\mathrm{N}_{2}$ fixing Cyanobacteria have the major advantage when sources of TIN are depleted from the lake water as a result of their Nitrogen fixation capabilities. Therefore, the obvious option that was investigated was nutrient fertilization as an attempt to control the N/P ratio. The common occurrence of Cyanobacteria blooms in Eutrophic lakes was worldwide documented [2] [7] and many others). Experimental studies of fertilization aimed at demonstrating the importance of low N/P ratio and the contribution of it to create optimal conditions for cyanobaterial blooms [2] [8]-[12]. were mostly related to temperate lakes. Moreover, the whole lake fertilization approach aimed at cyanobacterial blooms suppression were done in oligotrophic temperate ecosystems [4] [13] [14]: In the fertilized lakes the natural chlorophyll content was lower by 3 times and that of the Nitrate-by 10 times than the common values in the epilimnion of Lake Kinneret. The limnological features presented by [4] conclusively summarized their fertilization study: Development of nitrogen-fixing Cyanobacteria blooms is dependent on both a low N/P supply ratio and sufficient phosphorus supply. After the 1994 documentation of A. ovalisporum in lake Kinneret a study was carried out [6] [15] which was concluded: The multi-annual decline of Nitrogen loads in the epilimnion of Lak Kinneret reduced the N/P epilimnetic ratio (Figure 2). Supply of Nitrogen to the Kinneret ecosystem is mostly from external sources but Phosphorus sources are mostly internal and/or dust deposition. Therefore long-term drought regime were accompanied by a consequence of nitrogen deficiency in the lake whilst P stay constant or slightly elevated (Figure 3). Moreover, results in Figure 3 indicate P limitation condition. Therefore an unusual elevation of bio-available P in summer 1994 was suggested as one of the stimulator of the Aphanizomenon bloom: The loads of Particulate P (plankton and detritus) and total P were increasined (Figure 3) as a result of surplus phosphate but bio-available $\mathrm{P}$ concentration is declining as a result of intensive uptake of dissolved $\mathrm{P}$ by $\mathrm{P}$ limited consumers, phytoplankton. In other words, $\mathrm{P}$ is shifted from the dissolved compartment to the particulate food-web level. It has to be considered that although Nitrogen supply in winter was minimal during drought regime and is always dissipating during summer, the summer concentration is always extremely low and a decline of N/P ratio is resulted [11]. This process is expressed as seasonal and long-term effect [1] [6] [11]. The conclusion of our study [6] is the following: during the summer of 1994 optimal condition were available for the bloom burst of $A$. ovalisporum: Insufficient $\mathrm{N}$, and sufficient $\mathrm{P}$ concentrations
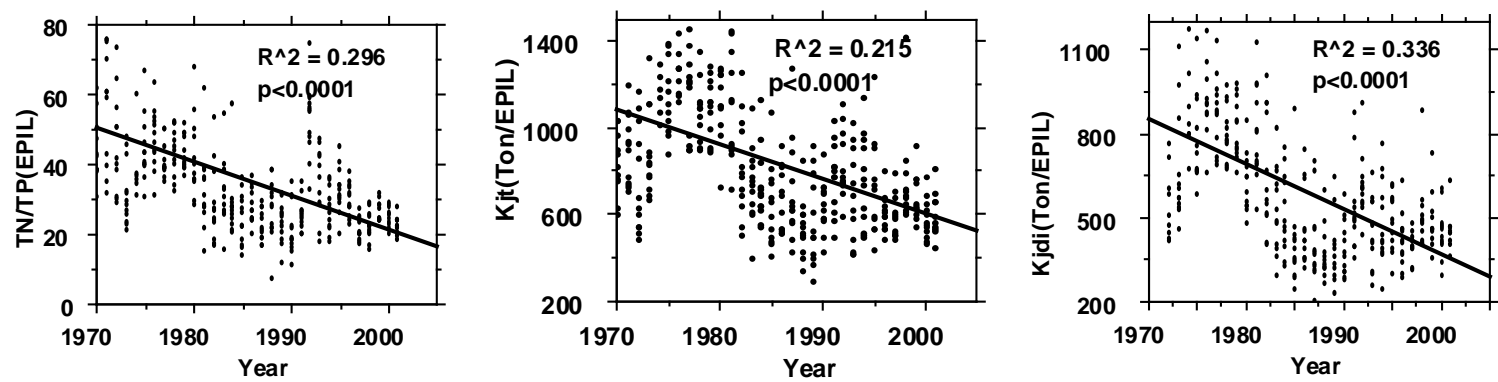

Figure 2. Nitrogen (TIN, Total and Dissolved Kieldhal and TN/TP ratio) and time (year) decline in the Epilimnion of Lake Kinneret during 1974-2004 Simple regression ( $\mathrm{r}^{2}$ and $\mathrm{p}$ values are given) between epilimnetic loads (tons) and time (year).
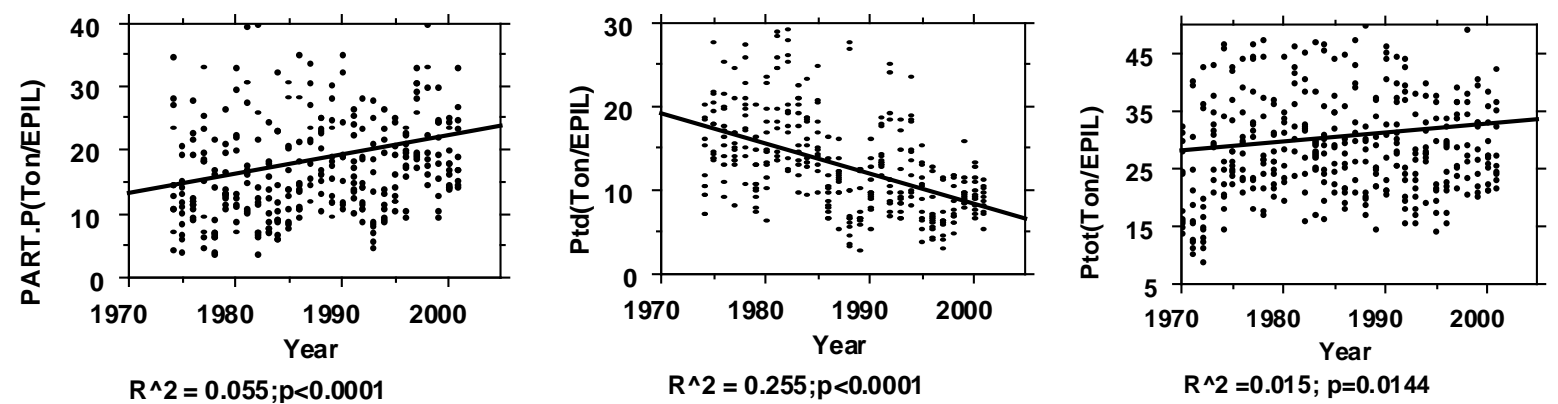

Figure 3. Phosphorus (P-total, P-total dissolved, and Particulate P) increase in the Epilimnion of Lake Kinneret during 1974-2004. Simple regressions ( $r^{2}$ and $p$ values are given) between epilimnetic loads (tons) and time (year). 
accompanied by appropriate filaments inoculum of the slow growth rated algae, A. ovalisporum, to create a bloom during last summer months (October-December) of 1994. The studies on the distribution of Cyanobacteria and their favored ecological conditions for bloom forming were performed on northern temperate-subarctic lakes [2] [3] [7] [11]. Moreover, the nutrient fertilization experimental studies were also carried out on northern temperate Lakes [4] [10] [14]. Nevertheless, these studies were carried out in Temperate lakes whilst Lake Kinneret is located in the sub-tropics. Lake Kinneret is a typical sub-tropical lake where the summer-fall season is long (June-October), hot (lake epilimnion- $26^{\circ} \mathrm{C}-30^{\circ} \mathrm{C}$ ), strong daily turbulence by routine 8 hours westerly wind and dry (no rain) and the winter is short (December-March), cold (epilimnetic Temps. $-15^{\circ} \mathrm{C}-17^{\circ} \mathrm{C}$ and wet (precipitation ranged $400-900 \mathrm{~mm} / \mathrm{y}$ directly on the lake and in the catchment respectively). The ecological dissimilarity existed between sub-tropical and temperate climate zones make comparative evaluation of the results to be done very carefully. The impact of low N/P ratio on cyanophytes bloom formation probably similar in both climate zones on the other hand due to eco-physiological differences of the food-web compartments, fertilization response might be differ. Another dissimilarity between lakes is related to the trophic status: cyanobacterial bloom formation in eutrophic or hypertrophic ecosystem is not compatible with oligotrophic trait. Undoubtedly Nitrogen limitation was gradually developt in the Kinneret ecosystem [16] and Cyanobacteria gain several benefits under such conditions: the ability to maintain $\mathrm{N}_{2}$ fixing, and therefore increased cell growth and also cell buoyancy together with the ability to regulate buoyancy to improve light absorbance and photosynthetic activity and cyanophyte cells growing under $\mathrm{N}$ limitation increase their capacity for Nitrogen uptake [17]. Nevertheless, Nitrogen deficit accompanied by decline of N/P ratio is not always counteracted by Nitrogen fixation. It can be concluded that the study presented here indicates no advantage of $\mathrm{N}_{2}$ fixing resulted by $\mathrm{N}$ deficit. Results in Figure 4 indicate lower number of filaments without additional Nitrogen and significant higher filament densities in tanks where Nitrogen was added. Moreover, the daily data indicates no difference in Nitrogen content of algal cells $\left(\mathrm{N}\right.$ (ppm)/Algal (g.dw), higher chlorophyll content when $\mathrm{N}$ was added and decline from day $1^{\text {st }}$
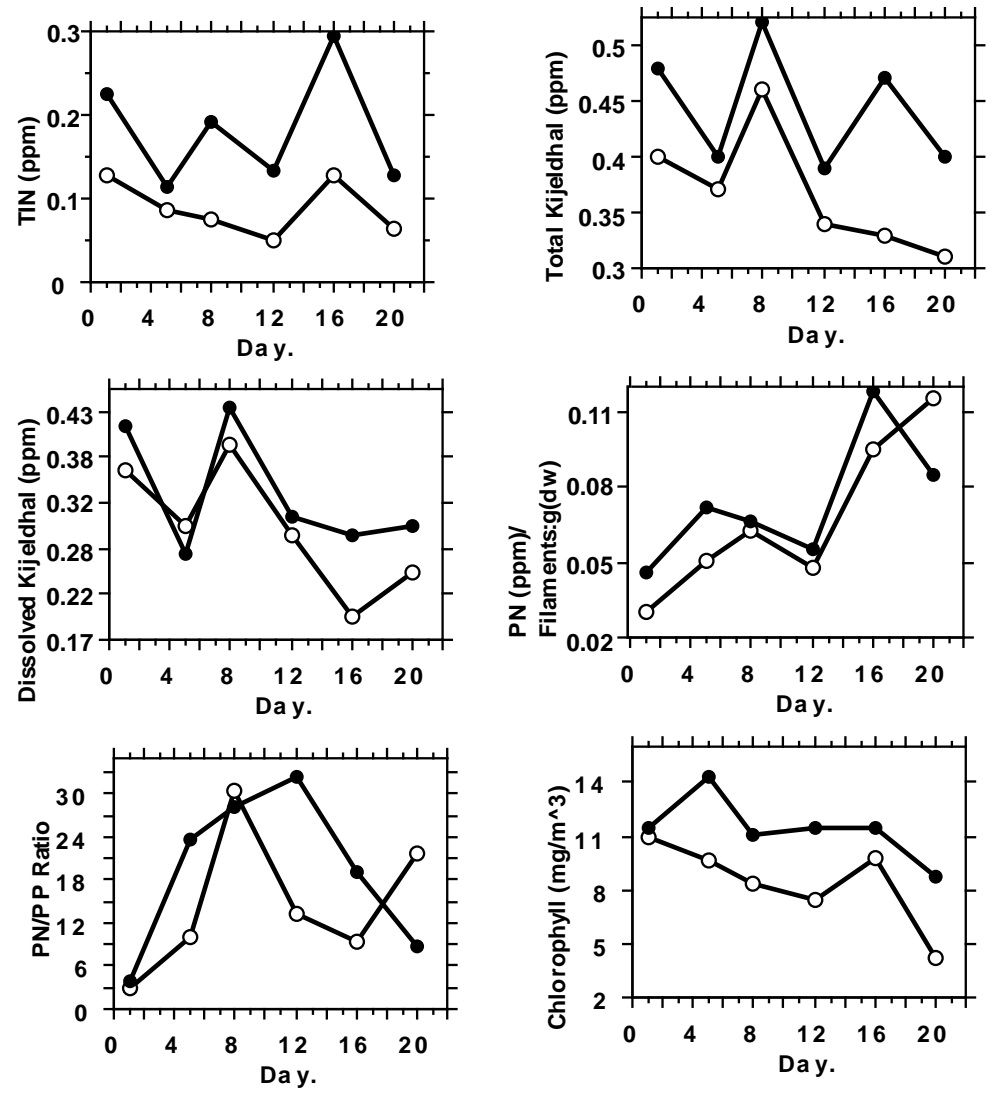

Figure 4. Daily fluctuations of chemical and biological parameters averaged For Tanks with additional (solid cycles) and without (open cycles) additional Nitrogen. 
to $6^{\text {th }}$ when $\mathrm{N}$ was not added. Additional nitrogen was clearly measured in the water in $\mathrm{N}$-added tanks. The concentration ranges of TIN measured in the tanks with and without additional Nitrogen $(0.05-0.300 \mathrm{ppm})$ were far below the critical level indicated by [17] as required (50 - 100 ppm) to induce nitrogenase activity. It is concluded that additional Nitrogen to natural Lake Kinneret waters including heavy bloom of A. ovalisporum was detected as dissolved form (TIN) in the water and contributed to the biomass (filament densities) increase, chlorophyll content but $\mathrm{N}_{2}$ fixing activity was probably slightly enhanced and fixers were not reduced. Normal activity of A. ovalisporum was not interfered by low concentrations of Nitrogen addition which slightly enhanced biomass density. These results must be thoroughly considered for future experimental design with higher $\mathrm{N}$ added concentration and longer time of incubation.

\section{Conclusion}

Bloom of Aphanizomenoin ovalisporum in Lake Kinneret was first recorded in summer 1994 resulted by multiannual decline of Nitrogen and slight increase of Phosphorus loads in the Epilimnion. The outcome was deficiency of Nitrogen and sufficiency of Phosphorus. An attempt to reduce the cyanophyte bloom was experimentally studied in outdoor $5 \mathrm{~m}^{3}$ by Nitrogen fertilization. It is suggested that because of the Eutrophic level of the Kinneret ecosystem and its location in a sub-tropical zone, the duration of the experiments should be longer than 20 days and higher quantity of additional Nitrogen should be tested. Not like in oligotrophic temperate lakes, the concept of Aphanizomenon suppression by additional Nitrogen which is in favor by other algae was not verified in this study. Under this experiment conditions, if extra $\mathrm{N}$ was given, or not given, the $\mathrm{N}$ fixing capability was not advantageous or disadvantageous to Aphanizomenon. Other factors, such as Phosphorus availability, temperature, turbulence, light absorption or zooplankton gazing, are probably deeply involved.

\section{Acknowledgements}

Thanks are given to Dr. O. Hadas, Kinneret Limnological Laboratory, for productive and friendly collaboration.

\section{References}

[1] Gophen, M. (2015) The Impact of Available Nitrogen Deficiency on Long-Term Changes in the Lake Kinneret Ecosystem. Open Journal of Ecology, 5, 147-157. http://dx.doi.org./10.4236/oje.2015.54013

[2] Smith, V.H. (1983) Low Nitrogen to Phosphorus Ratios Favor Dominance by Blue-Green Algae in Lake Phytoplankton. Science, 221, 669-671. http://dx.doi.org/10.1126/science.221.4611.669

[3] Taranun, Z.E., Gregory-Eaves, I., Leavitt, P.R., Buchaca, T., Katalan, J., Guilizzoni, P., Lami, A., McGowan, S., Moorhouse, H., Murabito, G., Mark, F.R., Stevenson, A., Thompson, P.L. and Vinerbrook, R.D. (2015) Acceleration of Cyanobacterial Dominance in North Temperate-Subarctic Lakes during the Anthropocene. Ecology Letters, 18, 375-384.

[4] Stockner, J.G. and Shortreed, K.S. (1988) Response of Anabaena and Synechococcus to Manipulation of Nitrogen: Phosphorus Ratios in Lake Fertilization Experiment. Limnology and Oceanography, 33, 1358-1361. http://dx.doi.org/10.4319/lo.1988.33.6.1348

[5] Liao, C.F.H. (1977) The Effect of Nutrient Enrichment on Nitrogen Fixation Activity in the Bay of Quinte, Lake Ontario. Hydrobiologia, 56, 273-279. http://dx.doi.org/10.1007/BF00017515

[6] Gophen, M., Smith, V.H., Nishri, A. and Threlkeld, S.T. (1999) Nitrogen Deficiency, Phosphorus Sufficiency, and the Invasion of Lake Kinneret, Israel, by $\mathrm{N}_{2}$-Fixing Cyanobacterium Aphanizomenon ovalisporum. Aquatic Sciences, 1. $1-14$.

[7] Barica, J., Kling, H. and Gibson, J. (1980) Experimental Manipoulation of Algal Bloom Composition by Nitrogen Addition. Canadian Journal of Fisheries and Aquatic Sciences, 37, 1175-1183. http://dx.doi.org/10.1139/f80-150

[8] Edmondson, W.T. and Lehman, J.T. (1981) The Effect of Changes in the Nutrient Income on the Condition of Lake Washington. Limnology and Oceanography, 26, 1-19. http://dx.doi.org/10.4319/lo.1981.26.1.0001

[9] Smith, V.H. (1982) The Nitrogen and Phosphorus Dependence of Algal Biomass in Lakes: An Experimental and Theoretical Analysis. Limnology and Oceanography, 27, 1101-1112. http://dx.doi.org/10.4319/10.1982.27.6.1101

[10] McQueen, D.J. and Lean, D.R.S. (1987) Influence of Water Temperature and Nitrogen to Phosphorus Ratios on the Dominance of Blue-Green Algae in Lake St. George, Ontario. Canadian Journal of Fisheries and Aquatic Sciences, 44, 489-699. http://dx.doi.org/10.1139/f87-073

[11] Flett, R.J., Schindler, D.W., Hamilton, R.D. and Campbell, N.E.R. (1980) Nitrogen Fixation in Canadian Precambrian Shield Lakes. Canadian Journal of Fisheries and Aquatic Sciences, 37, 494-505. http://dx.doi.org/10.1139/f80-064 
[12] Shapiro, J. (1973) Blue-Green Algae: Why They Become Dominant. Science, 179, 382-384. http://dx.doi.org/10.1126/science.179.4071.382

[13] Stockner, J.G. and Hyatt, K.D. (1984) Lake Fertilization: State of art after 7 Years of Application. Canadian Technical Report Fisheries and Aquatic Sciences, 1324, 33 p.

[14] Stockner, J.G. and Hyatt, K.D. (1985) Whole-Lake Fertilization Experiments in the Coastal British Columbia Lakes: Empirical Relationships between Nutrient Inputs and Phytoplankton Biomass and Production. Canadian Journal of Fisheries and Aquatic Sciences, 42, 649-658. http://dx.doi.org/10.1139/f85-084

[15] Gophen, M. (1999) Prediction of an $\mathrm{N}_{2}$-Fixing Cyanobacteria Bloom in Lake Kinneret (Israel) Based on N and P Balance. Verhandlungen des Internationalen Verein Limnologie, 27, 1239-1242.

[16] Gophen, M. (2011) The Cladoceran Trophic Status in the Nitrogen Limited Ecosystem of Lake Kinneret (Israel). Journal of Environmental Biology, 32, 455-462.

[17] Oliver, R.L. and Ganf, G.G. (2000) Chapter: Freshwater Blooms: Nutrition. XI: Nitrogen; XII: Responses of Cyanobacteria to N and P. In: Whitton, B.A. and Patts, M., Eds., The Ecology of Cyanobacteria: Their Diversity in Time and Space, Kluwer Academic Publishers, Boston, 176-183. 